\title{
Evidence Summary: Super-oxidised solutions for chronic wounds
}

January 2020

Author: Assoc. Prof. Emily Haesler, PhD

Wound Healing and Management Centre, Curtin University (WHAM@Curtin)

For referencing Haesler E. Evidence Summary: Super-oxidised solutions for chronic wounds. Wound Practice and Research 2020; 28(3):145-147.

DOI https://doi.org/10.33235/wpr.28.3.145-147

\section{CLINICAL QUESTION}

What is the best available evidence for using super-oxidised solutions (SOSs) to reduce infection and promote healing in chronic wounds in all populations?

\section{SUMMARY}

Super-oxidised solutions are a low cost topical antiseptic option for chronic wounds. Antibacterial, antimicrobial and anti-fungal properties of SOSs have been established in laboratory research ${ }^{1-7}$ (Level 5). Level 1 evidence from a systematic review ${ }^{8}$ and a randomised controlled trial $(\mathrm{RCT})^{9}$ showed SOS was as effective as povidone iodine in reduction microbial bioburden. Level 1 evidence from a systematic review $^{8}$ and four RCTs ${ }^{9-12}$ showed SOS was superior to both povidone iodine $e^{8,9,12}$ and saline ${ }^{9-11}$ for promoting healing, established using different outcome measures (e.g. percent of wounds healed, ${ }^{9}$ mean reduction in wound surface area, ${ }^{12}$ rate of healing ${ }^{9}$ and increase in granulation tissue). ${ }^{10}$ This evidence, together with additional Level $2^{13}$ and Level $4^{14-16}$ evidence, supported a Grade $B$ recommendation (a weak recommendation) ${ }^{17}$.

\section{CLINICAL PRACTICE RECOMMENDATIONS}

All recommendations should be applied with consideration to the wound, the patient, the health professional and the clinical context.

Super-oxidised solutions could be used to reduce local infection and promote healing in chronic wounds, particularly diabetic foot ulcers (Grade B).

\section{SOURCES OF EVIDENCE}

This summary was conducted using methods published by the Joanna Briggs Institute ${ }^{17-19}$. The summary is based on a literature search combining search terms related to SOSs and wounds. Only studies that used a solution described as super-oxidised on a chronic wound were included in the clinical evidence summary. Searches were conducted in CINAHL, Medline, the Cochrane Library and Google Scholar for evidence published up to December 2019 in English. Levels of evidence for intervention studies are reported in the table below.

\section{BACKGROUND}

Super-oxidised solutions are low concentration saltwater that have had an electrical current applied to increase ions in the solution $^{8,22}$. Super-oxidised solutions contain hypochlorous acid (HOCL) and sodium hypochlorite (NaOCL). However, not all HOCL solutions are super-oxidised. They are naturally acidic due to increased hydrogen ions, but some solutions are further processed to balance the $\mathrm{pH}$ (neutral) ${ }^{22}$. They may also be referred to as super-oxidised water, or most commonly by product names. ${ }^{\S}$ Bench research reports that SOSs have antibacterial ${ }^{1-3,6,7}$, antiviral ${ }^{5}$ and antifungal ${ }^{1}$ qualities against strains commonly observed in chronic wounds, including antibiotic-resistant bacteria ${ }^{2}$ and biofilm based organisms ${ }^{20,21}$. There is laboratory-based evidence that they reduce inflammatory markers ${ }^{4}$ (Level 5).

\begin{tabular}{|c|c|c|c|c|}
\hline $\begin{array}{l}\text { Level } 1 \\
\text { Evidence }\end{array}$ & $\begin{array}{l}\text { Level } 2 \\
\text { Evidence }\end{array}$ & $\begin{array}{l}\text { Level } 3 \\
\text { Evidence }\end{array}$ & $\begin{array}{l}\text { Level } 4 \\
\text { Evidence }\end{array}$ & $\begin{array}{l}\text { Level } 5 \\
\text { Evidence }\end{array}$ \\
\hline Experimental Designs & $\begin{array}{l}\text { Quasi-experimental } \\
\text { Designs }\end{array}$ & $\begin{array}{l}\text { Observational - } \\
\text { Analytic Designs }\end{array}$ & $\begin{array}{l}\text { Observational - } \\
\text { Descriptive Studies }\end{array}$ & $\begin{array}{l}\text { Expert Opinion/ } \\
\text { Bench Research }\end{array}$ \\
\hline $\begin{array}{l}\text { 1b. Systematic review } \\
\text { of RCTs and other } \\
\text { study designs } \\
\text { 1.c } \text { RCT }^{9-12}\end{array}$ & $\begin{array}{l}\text { Level 2.c Quasi- } \\
\text { experimental } \\
\text { prospectively } \\
\text { controlled study }{ }^{13}\end{array}$ & None & 4.c Case series ${ }^{14-16}$ & $\begin{array}{l}\text { 5.c Bench research }{ }^{1-7} \text {, } \\
20,21 \text { and single } \\
\text { expert opinion }{ }^{22}\end{array}$ \\
\hline
\end{tabular}

$\S$ Super-oxidised solutions in common use include (but are not limited to) Microdacyn ${ }^{\circledR}$, Dermacyn ${ }^{\circledR}$, Electromicyn ${ }^{\mathrm{TM}}$, Sterilox ${ }^{\circledR}$ and Microcyn ${ }^{\circledR}$. This information is included to assist health professionals in identifying products as the term 'super-oxidised solution' may not be included in labelling. WHAM@Curtin does not endorse any specific products. 


\section{CLINICAL EVIDENCE}

\section{Reduction in local infection}

- A systematic review reporting a range of studies reported that four studies showed SOSs are superior to povidone iodine as an antibiotic therapy, with bacterial clearance achieved after 3 weeks compared to 3.4 to 8.15 weeks for povidone iodine (Level 1).

- A single-blinded RCT at moderate risk of bias reported quantitative microbial analysis for post-surgical diabetic foot ulcers $(n=40)$ irrigated daily with either SOS or $50 \%$ povidone iodine/saline. The regimens were equally effective in controlling Gram positive and Gram negative bacteria, fungi and methicillin-resistant Staphylococcus aureus $\left(p=\right.$ not significant for all) ${ }^{9}$ (Level 1).

- In a prospective study at high risk of bias, infected diabetic foot ulcers undergoing surgery $(n=218)$ the odds ratio for successful reduction in bacterial burden when treated with an SOS compared with povidone iodine was 3.4 (95\% confidence interval [Cl] 1.7 to 7.0$)^{13}$ (Level 2).

- In a case series at high risk of bias, 19/20 diabetic foot ulcers treated with SOS soaked gauze were cleared of bacterial infection after a maximum of five days of treatment ${ }^{16}$ (Level 4).

Improvement in wound healing outcomes

- A systematic review reported that six studies showed healing rate range with SOSs was $6.9 \%$ to $65 \%$ compared to 50 to $62.5 \%$ with povidone iodine. Healing times reported in four studies were 5.1 to 5.3 weeks with SOS compared with 5.16 to 8.7 weeks with povidone iodine $^{8}$ (Level 1).

- A single-blinded RCT at moderate risk of bias showed healing rates for post-surgical diabetic foot ulcers ( $\mathrm{n}=$ 40) irrigated daily with SOS were superior to those with $50 \%$ povidone iodine/saline. Super-oxidised solution was associated with significantly greater percent of the wounds reaching complete healing at six months (90\% versus $55 \%$ for povidone iodine, $p=0.002)$. Mean healing time was also faster for SOS $(10.5 \pm 5.9$ weeks versus $16.5 \pm 7.1$ weeks, $\mathrm{p}=0.007)^{9}($ Level 1$)$.

- A single-blinded RCT at moderate risk of bias reported outcomes at 20 weeks for infected diabetic foot ulcers $(n=37)$ treated with SOS compared to treatment with saline. The SOS group experienced significantly better outcomes for reduction of cellulitis $(80.9 \%$ versus $43.7 \%, p=0.01$ ) and advancement of granulation tissue $(90.4 \%$ versus $62.5 \%, p=0.05)$. Participants in both groups received concurrent systemic antibiotics ${ }^{10}$ (Level 1).

- In an RCT at high risk of bias conducted with infected diabetic ulcers $(n=60)$, SOS dressings were associated with a significantly greater mean percentage reduction in area compared with povidone iodine dressings (58.90 $\pm 5.21 \%$ versus $40.90 \pm 8.76 \%, p=0.024)^{12}($ Level 1$)$.

- In a single-blinded RCT at high risk of bias, individuals with diabetes-associated wounds received twice daily application of either SOS-soaked or saline-soaked gauze. The SOS treatment was associated with statistically significantly more wounds being downgraded in severity after seven days $(p<0.05)^{11}$ (Level 1).

- In a prospective comparative study at high risk of bias, infected diabetic foot ulcers receiving surgery $(n=218)$ the median healing time when treated with an SOS was 43 days compared with 55 days for treatment with povidone iodine $(p<0.0001)^{13}$ (Level 2).

- Two case series at high risk of bias ${ }^{14,15}$ reported good outcomes with SOS. In the first, chronic wounds of mixed aetiology $(n=13)$, had a statistically significant reduction in wound surface area $(p<0.01)$ at one month, with about $53 \%$ of the wounds showing 20 to $40 \%$ reduction in wound area ${ }^{14}$. In the second case series, there was a $100 \%$ limb salvage rate and healing within a mean duration of 6.8 weeks for diabetic foot ulcers treated following surgical management of osteomyelitis $(\mathrm{n}=14)^{15}$ (both Level 4).

\section{CONSIDERATIONS FOR USE}

The following points could be considered when using SOSs:

- Super-oxidised solutions can be used as a wound irrigant, or can be applied to the wound as a gauzesoaked dressing, ${ }^{11,14,15}$ or can be used as an immersive soak to debride a wound ${ }^{10}$ (Levels 1 and 4).

- A SOS might help manage wound odour. In an RCT, SOS was associated with significant reduction in wound odour compared with saline treatment $(100 \%$ versus $25 \%, p=0.001)^{10}($ Level 1).

- A SOS might help manage wound pain. A case series at high risk of bias a SOS was associated with statistically significant reduction in wound pain scores $(p<0.001)$. The majority of participants had a main score of $5 / 10$ or lower prior to treatment ${ }^{14}$ (Level 4).

- The studies included in this evidence summary reported no major side effects associated with using SOS to treat a chronic wound.

\section{REFERENCES}

1. Gupta MK, Prakash P, Bharti S, Paswan AK, Singh DK, Tilak R. Superoxidised water: A promising disinfectant against bacterial and fungal pathogens Annals of Pathology and Laboratory Medicine, 2017;4(1):A-19-A22.

2. Gunaydin M, Esen S, Karadag A, Unal N, Yanik K, Odabasi H, Birinci A. In vitro antimicrobial activity of Medilox super-oxidized water. Ann Clin Microbiol Antimicrob, 2014. Jul 14;13:29.

3. Velazquez-Meza ME, Hernandez-Salgado M, Sanchez-Aleman MA. Evaluation of the Antimicrobial Activity of a Super Oxidized Solution in Clinical Isolates. Microb Drug Resist, 2015. Aug;21(4):367-72.

4. Medina-Tamayo J, Sanchez-Miranda E, Balleza-Tapia H, Ambriz X, Cid ME, Gonzalez-Espinosa D, Gutierrez AA, Gonzalez-Espinosa C. Super-oxidized solution inhibits IgE-antigen-induced degranulation and cytokine release in mast cells. Int Immunopharmacol, 2007. Aug;7(8):1013-24.

5. Landa-Solis C, Gonzalez-Espinosa D, Guzman-Soriano B, Snyder M, Reyes-Teran G, Torres K, Gutierrez AA. Microcyn: a novel superoxidized water with neutral $\mathrm{pH}$ and disinfectant activity. J Hosp Infect, 2005. Dec;61(4):291-9.

6. Zinkevich V, Beech IB, Tapper R, Bogdarina I. The effect of superoxidized water on Escherichia coli. J Hospital Infection, 2000;46:153-6. 
7. Shetty N, Srinivasan S, Holton J, Ridgway GL. Evaluation of microbicidal activity of a new disinfectant: Sterilox 2500 against Clostridium difficile spores, Helicobacter pylori, vancomycin resistant Enterococcus species, Candida albicans and several Mycobacterium species. J Hosp Infect, 1999. Feb;41(2):101-5.

8. Eftekharizadeh F, Dehnavieh R, Noori Hekmat S, Mehrolhassani MH. Health technology assessment on super oxidized water for treatment of chronic wounds. Med J Islam Repub Iran, 2016;30:384.

9. Piaggesi A, Goretti C, Mazzurco S, Tascini C, Leonildi A, Rizzo L, Tedeschi A, Gemignani G, Menichetti F, Del Prato S. A randomized controlled trial to examine the efficacy and safety of a new superoxidized solution for the management of wide postsurgical lesions of the diabetic foot. Int J Low Extrem Wounds, 2010. Mar;9(1):10-5.

10. Martínez-De Jesús FR, Ramos-De la Medina A, Remes-Troche JM, Armstrong DG, Wu SC, Lázaro Martínez JL, Beneit-Montesinos JV. Efficacy and safety of neutral $\mathrm{pH}$ superoxidised solution in severe diabetic foot infections. Int Wound J, 2007;4:353-62.

11. Hadi SF, Khaliq T, Bilal N, Sikandar I, Saaiq M, Zubair M, Aurangzeb S. Treating infected diabetic wounds with superoxidized water as anti-septic agent: A preliminary experience JCPSP, 2007;17(12):7403.

12. Prabhakar KBS, Purushotham G, Uma K. Comparison of superoxidized solution versus povidone iodine in management of infected diabetic ulcers: Our experience. IAIM, 2016;3(5):151-8.

13. Dalla Paola L, Brocco E, Senesi A, Merico M, De Vido D, Assaloni R, DaRos R. Super-oxidized solution (sos) therapy for infected diabetic foot ulcers Wounds Int, 2006;18(9):262-70.

14. Nair H. Combined super-oxidized therapy: an effective treatment for chronic wounds. Wounds Asia, 2018;25-7.
15. Aragon-Sanchez J, Lazaro-Martinez JL, Quintana-Marrero Y, SanzCorbalan I, Hernandez-Herrero MJ, Cabrera-Galvan JJ. Superoxidized solution (Dermacyn Wound Care) as adjuvant treatment in the postoperative management of complicated diabetic foot osteomyelitis: preliminary experience in a specialized department. Int J Low Extrem Wounds, 2013; 12(2):130-7.

16. Chittoria RK, Yootla M, Sampatrao LM, Raman SV. The role of super oxidized solution in the management of diabetic foot ulcer: our experience. Nepal Med Coll J, 2007; 9(2):125-8.

17. Joanna Briggs Institute Levels of Evidence and Grades of Recommendation Working Party. New JBI Grades of Recommendation. Adelaide: Joanna Briggs Institute; 2013.

18. Aromataris E, Munn Z, editors. Joanna Briggs Institute Reviewer's Manual. https://reviewersmanual.joannabriggs.org/. The Joanna Briggs Institute; 2017.

19. The Joanna Briggs Institute Levels of Evidence and Grades of Recommendation Working Party. Supporting Document for the Joanna Briggs Institute Levels of Evidence and Grades of Recommendation. www.joannabriggs.org: The Joanna Briggs Institute2014.

20. Johani K, Malone M, Jensen SO, Dickson HG, Gosbell IB, Hu H, Yang Q, Schultz G, Vickery K. Evaluation of short exposure times of antimicrobial wound solutions against microbial biofilms: From in vitro to in vivo. The Journal of Antimicrobial Chemotherapy, 2018;73(2):494-502.

21. Sauer K, Thatcher E, Northey R, Gutierrez A. Neutral super-oxidised solutions are effective in killing P.aeruginosa biofilms. Biofouling, 2009;25(1):45-54.

22. Chan L. 2015. Super-oxidised Solution. Available from: https://www. dermnetnz.org/topics/superoxidised-solution/. [Accessed Jan 2020].

\section{Coloplast Biatain Literary Awards}

\section{Wound Practice \& Research, the Australian Journal of Wound Management and Coloplast Australia are pleased to offer three Coloplast Biatain Literary Awards.}

\section{These awards are designed to encourage and reward those who publish their wound care clinical experience. The awards acknowledge excellence of original manuscripts, case presentations and clinical research undertaken within Australasia, both novice and advanced.}

Each winner of the Coloplast Biatain Literary Award receives $\$ 1000$ to be used towards future endeavours in wound management. To enter you must be the first-named author of a manuscript published in Wound Practice \& Research Journal. Manuscripts must relate to a case study, original research or a literature/clinical practice review, authors are preferably members of Wounds Australia.

Judged by the Editorial Board of Wound Practice \& Research annually, one award per category is given based on published articles in the calendar year.

Coloplast manufactures Biatain, Biatain Ag, Biatain Ibu, Biatain Silicone, Biatain Silicone Lite, Biatain Super, Biatain Alginate, Comfeel Plus Transparent and Ulcer dressings which provide integrated solutions in wound healing. Coloplast Wound Care is committed to the development of excellence in wound management practices.

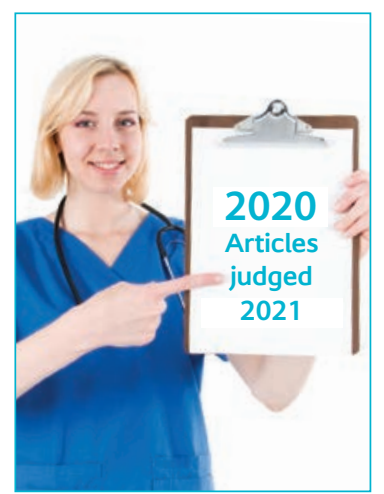

